\title{
若手会員の会 活動報告
}

http://wwwsoc.nii.ac.jp/jws/welnet/

(若手会員の会からのお知らせはホームページにも掲載しています)

\section{第6回日韓若手研究者シンポジウム・AWF シンポジウム 合同会議開催のご案内}

\section{若手会員の会運営委員会委員 佐藤 裕（東北大学）}

\section{Information of Joint Hosting of the 6th KWJS-JWS Symposium}

\section{of Young Researcher and AWF Symposium}

若手会員の会では, 第 6 回日韓若手研究者シンポジウ ムとAWF（アジア溶接連盟）シンポジウムの合同会議を 下記のとおり開催いたします。

\section{会議名：第 6 回日韓若手研究者シンポジウム・AWF シン} ポジウム合同会議

日時：平成 22 年 4 月 22 日（木） 9 ： $30 \sim 12$ : 30

場所 : 東京ビックサイト（春季全国大会第 4 会場） プログラム :

Opening address $(9: 30 \sim 9: 40)$

The 1st session $(9: 40 \sim 10: 55)$

1. Intelligent Optimization Methodology for Welding Parameter in Aluminum Laser Welding with Filler Wire

Young Whan Park (Pukyong National University)

2. High-Quality Welds of Stainless Steel with $10 \mathrm{~kW}$ High-Power Fiber Laser

Yousuke Kawahito, Seiji Katayama (Osaka University)

3. Friction Stir Welding of Dissimilar Butt Joint Between Titanium and Aluminum Alloys

Jae-Keun Hong, Chae-Hun Lee, Jong-Taek Yeom, Jeung-Han Kim, Chang-Gil Lee, Nho-Kwang Park (KIMS)

4. Material Flow during Friction Stir Spot Welding Shohei Horie, Kenji Shinozaki, Motomichi
Yamamoto, Hirotaka Nakashin (Hiroshima University), Thomas H. North (University of Toronto)

5. Lattice Boltzmann Simulation of $\mathrm{CO}_{2}$ Laser Interaction with Weakly-Ionized Helium Plasmas Huayu Li, Hyungson Ki (U1san National Institute of Science and Techonology) Break $(10: 55 \sim 11: 10)$

The 2 rd session $(11: 10 \sim 12: 25)$

6. Influence of Material Layout on Nugget Formation of Single-Side RSW

Hitomi Nishibata, Syota Kikuchi, Manabu

Fukumoto, Masato Uchihara (Sumimoto Metal)

7. Effect of Response Time of Welding Current in Invert DC Spot System on Weldability of Aluminum Alloy Sheet

Dong Cheol Kim, In Sung Hwang, Mun Jin Kang (KITECH)

8. Numerical Simulation of Microscopic Stress in SCC Test Specimen Considering Crystalline Orientation Distribution

Yoshiki Mikami, Keisuke Sogabe, Ryosuke Uraguchi, Masahito Mochizuki (0saka University)

9. Investigation on Interfacial Reaction and Reliability for $\mathrm{Sn}-3 \mathrm{Ag}-0.5 \mathrm{Cu}, \mathrm{Sn}-0.3 \mathrm{Ag}-0.7 \mathrm{Cu}$ and $\mathrm{Sn}-\mathrm{Pb}$ solder joint under thermal shock 
Chul Min Oh, Wong Sik Hong (KETI)

10. Visualization of Fume Generation Process in Arc Welding with Numerical Simulation

Shinichi Tashiro, Tasuku Zeniyaa, Manabu

Tanaka, Kazuhiro Nakata (Osaka University), Anthony B. Murphy (CSIR0), Eri Yamamoto, Kei Yamazaki, Keiichi Suzuki (Kobe Steel)

Closing address $(12: 25 \sim 12: 30)$
日韓若手研究者シンポジウムは日韓, AWF シンポジウ ムはアジア全体を対象とした溶接研究者の学術的・技術 的情報交換ならびに人的ネットワーク形成の場となって います。これらシンポジウムをきっかけにして，国際共 同研究に結び付いた例もあります. 若手研究者に限らず, 国際交流に興味がある方，アジア溶接界の現状を知りた い方など是非会場までお越し下さい。若手会員の会では 皆様の参加を心から歓迎いたします.

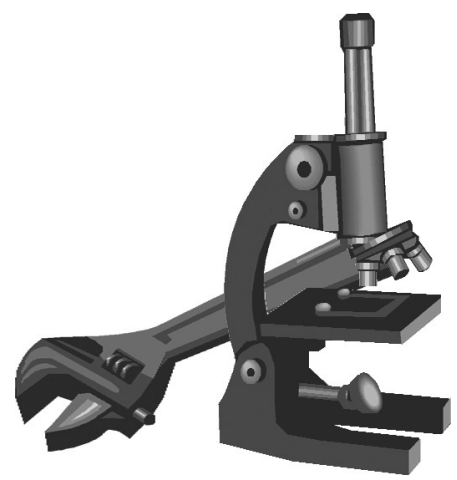

\section{読者の Goiken-bako (御意見箱) 受付中！＼cjkstart皆様の御意見をお聞かせください}

「自由編集ページ」として若手会員の会から毎号メッセージをお送りさせていただいております。さらに内容の充実 を図るために読者の皆様の御意見・御感想をお聞かせください. 若手会員だけでなく幅広く御意見をいただければ幸 いです，皆様からの御意見は「若手会員の会 運営委員会」で参考にさせていただきます。下記の項目について御回答 の上，郵送，F A Xまたは電子メールでお送りください。お送りいただいた方の中から抽選で毎号 1 名様に特製テレ ホンカードを差し上げます.

送付先：溶接学会 若手会員の会「Goiken-bako」係

干 101 東京都千代田区神田佐久間町 1-11

E-mail : t-welnet@ijk.com

FAX:03-3253-3059
(Subject に "Goiken-bako" と御記入ください)

$\lceil$ Goiken-bako」記入項目

（1）氏名, フリガナ, 年齢, 溶接学会入会年, 所属, 住所（テレホンカード送付先）

(2) 何月号についてお答えいただけますか.

(3-1)今月の「自由編集ページ」について次の中からお答えください.

(3-2) 今月の「自由編集ページ」についての御意見・御感想.

(4-1) 今月の溶接学会誌の全ての記事の中で, 興味のある記事（ページ番号でお答えください）.

(4-2) 今月の溶接学会誌についての御意見・御感想.

(5) 今後「自由編集ページ」や溶接学会誌で取り上げて欲しい記事.

(6) その他, 若手会員の会, 溶接学会の各種活動についての御意見・御感想. 